Journal of Social Sciences (COES\&RJ-JSS)

ISSN (E): 2305-9249 ISSN (P): 2305-9494

Publisher: Centre of Excellence for Scientific \& Research Journalism, COES\&RJ LLC

Online Publication Date: $1^{\text {st }}$ April 2016

Online Issue: Volume 5, Number 2, April 2016

http://centreofexcellence.net/J/JSS/JSS\%20Mainpage.htm

\title{
Leadership Strategy To Enhance Islamic Education Quality: A Single Case Study at Darush-sholihin Boarding Schools in Nganjuk, East Java, Indonesia.
}

\author{
Suyitno \\ Higher School of Economics Indonesia, \\ Malang, East Java, Indonesia \\ Supriyono \\ Balitar Islamic University, Blitar, Indonesia
}

\begin{abstract}
:
This is a single case study aiming at describing the implementation of leadership, the leadership behavior, and the implementation of participative decision making at Darushsholihin Boarding School in Nganjuk, East Java, Indonesia. This descriptive qualitative research used participative observation, interview, and documentation. The interactive analysis as advised by Huberman (1992) was employed. This research concluded that the leadership implementation consisted of enhancing the staffs and teachers professionalism and the academic and non academic achievements of the students. The leadership behaviour turned to be the tendency to benchmark, to conduct leaders and teachers discussions, to grow ruchul jihad, to promote reading habits, to promote partnership with parents and related parties, and to give continuous motivation. The decision making turned out to involve principals, staffs, teachers, and the community.
\end{abstract}

\section{Key Terms:}

Leadership, Islamic Education, Quality

\section{Citation:}

Suyitno; Supriyono (2016); Leadership Strategy To Enhance Islamic Education Quality: A Single Case Study at Darush-sholihin Boarding Schools in Nganjuk, East Java, Indonesia; Journal of Social Sciences (COES\&RJ-JSS), Vol.5, No.2, pp: 165-171. 


\section{Introduction}

Education is a process to enhance the quality of human resources in terms of knowledge, skills, and attitude to enhance the better life of human beings. Education become the responsibilities of not only the government, but also the community. According to the amended 1945 constitution of the Indonesia Republic, the government must make efforts and conduct a national education system that can enhance the devotion and faith to the Lord Almighty and develop good morals to educate the life of the nation. The governmental decree no 20 year 2003 describes that the national education functions as developing the competence and forming the nation characters and dignified civilization to educate the life of the nation. Therefore, the national education is aimed at educating students to be devoted and faithful as well as moralled human beings who are healthy, acknowledgeable, competence, creative, and independent, responsible, and democratic. Such objectives can be achieved through the Islamic education.

The Islamic education institution such as the Islamic boarding schools called Pesantren initially was lack of attention from the community group and middle class to higher class community. However, recently the perception has changed. Several researches showed that there have been significant relationships among the professionalism, roles implementation of the Islamic institution personals with the better achievement of the education process in the Islamic education institution (Imron, 1998, 21). These also showed the the organization became effective with their professionalism and the managed roles implementation. They succeeded in growing the team work climate. Such action can stir the resources for effective and efficient empowerment (Gorton, R., 197:178).

Such phenomenon turned out to happen in the Darush-sholihin boarding schools in Nganjuk, East Java, Indonesia. The leadership implementation, the leadership behaviour, and the decision making seemed to be powerful to enhance the quality of their education. Therefore, this was very interesting to study. Considering that finding the ways how leadership was implemented in the Islamic boarding schools was very useful due to the recent attention to the Islamic education, this study was conducted to explore the leadership strategy in enhancing the quality of the Islamic education at the Darushsholihin boarding schools in Nganjuk, East Java, Indonesia.

The focuses of this study were the implementation of the leadership strategy, the leadership behaviour, and the participative decision making. This study was aimed at describing the implementation of the leadership strategy, the leadership behaviour, and the participative decision making. This study has academic, and practical significances and the results were expected to contribute inputs to the education management, principals, and the community.

\section{Theoretical Review}

Leadership is the ability of a person to influence others in order that other people behave as what the leader expect (Soekamto, 1987:264). Mar'at (1984) states that a leader is a person who has special ability with or without being legitimated to influence groups being led to work for certain objectives. Leadership is also perceived as the enhancement of the influence bit by bit for the mechanistic compliance to routinely lead organization (Madhi, 1411H:2). Indirectly, this indicates of the existence of influences to change behaviour (Mar'at, 1984:18). In the context of schools, school community including principals, teachers, staffs, and students have to mutually support and work in team to 
achieve the determined objectives as led by the principals (Gorton, 197:178). The success of the schools as organization can depends on the leaders. Leaders have to understand leadership which is also according to Lovel (1983:34) leadership is an ability and readiness of a person to influence, support, invite, move, and event force other people to accept his influence and do what he lead to achieve the objectives. A good leadership is one that integrate the tasks and relationship orientations (Hoy, and Miskel, 1987:65). An effective leader is one who can harness teamwork in achieving the objectives (Gorton, 197:45). This is in line with what Soetopo (1982:22) state that a leader is the one who is capable to stir, direct, guide, and control for achieving certain objectives.

Effective leadership can be implemented by using some leadership approaches. Yulk (1989) classifies this into power and influence, traits, behaviour, and situational. Owen (1987), , Hoy and Miskel (1987), and Robins (1984) classify these into three including traits, behaviour, and contingency and situational. Effective leaders use combination of the approaches and powers. In terms of the traits approach. There are 10 traits to own by a leader which include physical and spiritual energy, comprehension of objectives and means, enthusiasm, effectiveness and friendship, personal integrity, technical conversation, ease of the decision, smartness, teaching ability, and loyalty. The main 4 traits including intelligence, maturity and social perception immensity, motivation and achievement orientation, and ability of human relation. These 4 traits empower the ability to see the whole organization, the ability to take decision, ability to delegate, and ability to develop loyalty. Leaders do not only rely on the traits, but also behaviour. According to Hoy and Miskel (1987), leadership behaviours can be classified into two groups, which are goal achievement and group maintenance. Leadership style is very important as a continuum depending on the situation. There are three factors who determine the success of a leaders which are relationship among leaders, tasks structures, and power relations. These can be the power base of the leadership (Harsey and Blanchard, 198). Fedler sais that a leader can determine a situation. A leader, then, has to adapt his behaviour. Soekamto (1987:226) states that leadership types are also important. Educational leadership types are formed as results of social organization made of the dynamic social interaction. In relation to this there are four types of leadership, which are autocratic, democratic, exclusive, and intellectual. The autocratic leaders tend to stir and force the followers (Soekamto, 1987:226). Such leaders believe that he is the main factor of the organization success (Soekamto, Indrafahrudin, Soetopo, 1984:46). Sometimes, team communication is not needed in such types of the leadership. Schools are perceived as static and discussion is perceived as time consuming (Nawawi, 1985:91). Such leadership type, according to Faisal (1984:27) will not work, because the community is a determination factor of the success of education. Depag, RI (1983:103) wrote the Holy Qur'an verse of which the Lord Almighty revealed that human beings not to behave sarcastically, because the followers will leave the leaders.

Some leaders use the liaise Faire type of leadership by which the leaders also give spare rooms for the followers to work for achieving the goals in their own way (Sutisna, 1983:265). Purwanto (1990:50) criticise this type of leadership because of the lost control from the leaders. However, in more democratic way, followers can be given opportunities to involve in educational policies and programs (Soetopo and Soemanto, 1982:285). Such leaders will always be in the middle of the followers (Purwanto, 1990:48). They always consider the followers suggestions (Sutisna, 1983:265).

The implementation of educational leadership has the foundations of idealism, structuralism, operationalism, and religion. The idealism is based on the so-called the 
Pancasila or Five Principals. The structuralism is based on the 1945 constitution of the Indonesia Republic, and the religion is based on Al Qur'an (UUD 145, Indrakusuma, 1973:2000, Al Qur'an). In leading people, leaders use their leadership behavioural concept. Yukl (1994) states that the leaders' behaviour towards the followers comprise four types of behaviours, which are high task and high relationship, high task and low relationship, low tasks and high relationships, and low task and low relationships (Yukle, 1994). The behaviour oriented to tasks focuses on the leaders; on the other hand, that of which is oriented to relationship focuses on the followers. Harsey and Blachard (1977) formulates such behaviours in the situational leadership. Leaders can choose the behaviour which suit the situation and this can make the leadership effective. When the followers are satisfied and the leaders succeed to achieve the organisational goals, there is the tendency that leaders influence the view of the organizational objectives as being explained in the objective line theory. On the other way, leaders can make their leadership effective by differentiating the human attention and the outcome attention as explained in the managerial grid theory. All such leadership effectiveness can influence the quality of education.

Education is a process involving lots of component to achieve certain goals (Yusuf, 1982:21). This is done to educate children within their physical and spiritual growth to reach their maturity (Indrakusuma, 1973). In such efforts, the quality education must be developed. There were theoretical references that can be used to develop the quality of education. Empirical theory introduced by John Locke (1932-1704) believes that human growth is influenced by the human environment (Tim Dosen FKIP, 1987:8). Nativism theory by Arthur Sholpenhour (1788-1860) believes that human growth is infulenced by the heredity. Their real potential will determine the success of their education (Tim Dosen FKIP, 1987:9). Meanwhile, William S Tern (1871-198) believes that the combination of both theories determine the success of human growth to be mature and to succeed in their education ((Tim Dosen IKIP, 1987:10-11).

The objectives of education are the determination of people ideals to be reached. The ultimate goal is to make children mature (Yusuf and Romdiah, 1989:45). This is in line with the national education the Indonesia Republic as developing the ability and characters as well as the dignified civilization of a nation with having children to be faithful, good in morale, healthy, competent, creative, independent, and democratic (Decree of the Indonesia Republic No 20, 2003). Such objectives can be attained with the educational innovation. Innovation is very important because the future community is the open community that always seek quality. Innovation is identified as a conceptual and perceptual analysis on the opportunity and possibility. Innovation should be simple and begun from a small thing. Innovation can be done through an effective leadership. The innovation should be done genuinely that focus on the simple thing with directed conceptual and perceptual ideas (Drucker, 1988). In educational area, such innovation is also done in the madrasa or the Islamic boarding schools. With good quality of the Islamic boarding schools, the students can easily move to other public schools and vice versa when this situation should happen to students (Hasbullah, 1996:182). Therefore, it is highly recommended to formulate a model of the Islamic boarding school innobation (Fadjar, 1998:81).

The leadership strategies also determine the success of educational leadership. The leadership function in educational administration relate to the activities of planning, organizing, maintaining, and completing facilities and human resources which involve in 
instructional management, people management, and schools-community relation management (Subroto, 1984:19). All efforts to manage all schools activities are considered the domain of the instructional management (Fachrudi and Soetopo, 1989:66). Such management will need strategies to be implemented.

\section{Reseach Method}

The research context is the Darush Shihin Islamic Boarding Schools in Nganjuk, East Java, Indonesia. These schools are managed by Islamic foundation and comprise integrated Islamic kindergarten and Islamic Primary schools with combined religious and scientific learning. This is a case study using interview, participative observation, and documentation. This study uses the interactive data analysis (Hubberman, 1992). The objectives of this study is to describe empirical phenomenon reality naturalistically (Moleong, 1996). The case study was also considered as a strategy to study the phenomenon completely and in detail (Bogdan and Bkilen, 1982). The study was done by having the following procedures, (1) preliminary studies, filed studies, and intensive analysis. The samples were taken by snowballing techniques (Sutopo, 1988). The informen were determined by using 5 criterias intriduced by Spreadley (1980) including the intensive, active, timely, realistic, and infamiliar respondents. These include the foundation leaders, principals, teachers, and administrators. The participative observation was done with the in-depth interview and documentation (Nasution, 1988, Mantja, 1994). The data was ensured to be qualified by having to check the credibility, transferability, dependability, and conformability.

\section{Findings}

In terms of the leadership implementation it was found out that the school leaders conducted the enhancement of the teachers and staffs professionalism and enhancement of the students academic and non academic achievements. The enhancement of the teachers and staffs professionalisms were done by (a) developing the point of views of the teachers and staffs by sending them for training and workshops, (b) motivate teachers and staffs to enhance discipline, and (c) benchmark in qualified schools, (d) involve teachers and staffs for the association of the subject matters, and (e) enhancing the compensation and benefits of the teachers and staffs. The enhancement of the students achievement was done by (a) enhancing the quality and discipline of the teachers, (b) enhancing the students' discipline in learning and in making their own classroom regulation, (c) motivate students to like learning with off and on class facilities and activities, (d) provide complete learning facilities, (e) provide conducive learning environment, (f) empower all school resources effectively. They also provide additional afterschool activities to students, conduct competition, and provide extra curricular activities such as boy scouts and cpr.

In terms of the leadership behaviours, it was found out that leaders of the Darush Sholihin Islamic foundation used a strategy called "Jurus DUIT" or DUIT ways. DUIT stands for discipline (Ind: Disiplin), Efforts (Indo:Efforts), Sincere (Indo:Ikhlas), and God-fearing (Indo:Taqwa).Therefore there were always close relationship among leaders and followers allowing the combination of high tasks and high relationships, even though the followers have been highly competent. Such strategy is implemented through benchmarking, close discussion with teachers and staffs, having the so called Ruhul Jihad development which is valuing every potential and giving opportunity to take action, having the reading movement, developing networking with related parties, and giving continuous motivation.

The participative decision making turned out to be conducted by involving all educational and foundation components positively, at least those including teachers, staffs, principals, 
and the community, giving rooms for students to express their ideas at the instructional activities, having parenting sessions and meetings, and creating a networking posts in the community to gain the community participation, and empowering the school committee consisting of the representation of parents, the representation of the community leaders, the representation of education experts, the representation of corporation or small businesses, the representation of the alumni, the representation of the foundation, and the representation of the local government. This means that the schools implemented the socalled triple helix system in the entrepreneurial leadership.

These actions tend to relate with the situational leadership, fulfil the principles of the education quality development as mandated by the constitution of the Indonesia Republic, genuinely work for the attainment of the educational objectives as well as educational innovation, and ultimately enhance the quality of education as a whole.

\section{Conclusion and Recommendation}

It has been concluded that the leadership implementation involved the enhancement the teachers and staffs quality to support the instructional process and the enhancement of the students' academic and non academic achievements. The leadership behaviour involved the combination of high tasks and relationships in response to the educational innovation by benchmarking, discussion of teachers and staffs, Ruhul Jihad development, reading movement, networking, and continuous motivation supports. The participate decision making involved three important aspects including teachers and staffs, principals, and the community. The community participation concerns with the funding and non funding supports.

It has been recommended that the principals always enhance and maintain the good strategies and leadership implementation. The government has been suggested to supports with experts and facilities to implement effective leadership. Teachers have been advised to enhance their participation in the development of the education quality with the effective leadership implementation. Finally, the school committee was advised to enhance their participation in the development of the educational quality of the schools.

\section{References}

Al Qur'an

Arifin, I (1998)Kepemimpinan Kepala Sekolah. Disertasi. IKIP Malang

Bogdan, R.C. dan Biklen, S.K.(1982).Qualitative Research for Education, An Introduction to Theory and Methods.Boston:Allyn dan Bacon, Inc

Depag.RI(1983). Al Qur'an dan Terjemahan.Proyek Pengadaan Kitab Suci Al Qur'an

Drucker, P.F.(1997)"My life as a Knowledge Worker, Inc"19(February).76-82

Drucker,P(1988) The Coming of the New Organization, Harvard Business Review on Knowledge Management, Harvard Business School Press, 1998, pp 119

Fajar, M(1995)Tantangan dan Peran Umat Islam Dalam Menyongsong Abad XII. Makalah.IAIN Surabaya

Faisal, S(1987)Sosiologi Pendidikan.Surabaya:Usaha Nasional

Gorton, A.(1977).School Administration, America:W.M.C. Brown Company Publisher

Hasbullah.(1999).Dasar-Dasar Ilmu Pendidikan.Jakarta:Raja Grafindo Persada 
Hasan, M.A dan Ali, M.(2003). Kapita Selekta Pendidikan Islam.Jakarta:

Pedoman Ilmu Jaya

Hersey, P. and Blanchard, K. H. (1977). Management of Organizational

Behavior: Utilizing Human Resourcesl. (3rd ed.) New Jersey, Prentice Hall.

Hoy, dan Miskel(1987).Educational Administration.New York: Random House

Hubberman, M(1992)Qualitative Data Analysis.New Jersey: Prantice Hall

Indrakusuma, A.D. (1973).Pengantar Ilmu Pendidikan.Surabaya: Usaha Nasional

Indrafahrudin, S dan Soetopo, H(1984)Administrasi Pendidikan,Jakarta:Mutiara

Kartono, K.(1994).Pemimpin dan Kepemimpinan.Jakarta:PT Raja Grafindo

Lovel, J.T (1983).Supervision for Better School.New Jersey:Prnatice Hall Inc.Englewoods Cliffs

Mandhi, J.(1411H).Menjadi Pemimpin yang efektif dan berpengaruh tinjauan Manajemen Kepemimpinan Islam, Jeddah, tt

Mantja, W(1994).Teknik Wawancara Mendalam.Malang, Lemlit IKIP Malang

Mar'at(1984).Pemimpin dan Kepemimpinan.Jakarta:Ghalia Indonesia

Moelong, L.J.(1996).Metodologi Penelitian Kualitatif.Bandung:Remaja Rosda Karya

Nawawi, H.(1995) Administrasi Pendidikan.Jakarta:Gunung Agung

Nasution, S.(1988)Berbagai Pendekatan Dalam Proses Belajar Mengajar. Jakarta:Bina Aksara

Owens, R(1987).Organiational Behavior in Education.New Jersey:Prantice Hall,Inc Engle Wood Cliffs

Purwanto, N(1990). Administrasi dan Supervisi Pendidikan.Bandung:Remaja Rosda Karya

Spreadley(1980).Participant Observation.New York:Reinhart and Winston

Soetopo, H dan Soemanto, W(1982).Pengantar Operasional Administrasi Pendidikan. Surabaya:Usaha Nasional

Stephen, R(1984)Essential of Organiational Behavior in Education.New Jersey:Prantice Hall Inc.

Subroto, B.Suryo.(1984).Dimensi-dimensi Administrasi Pendidikan di Sekolah.Jakarta:Bina Aksara

Sutisno, O(1983)Administrasi Pendidikan.Bandung:Rosda

Sutopo, H.B.(1988)Konsep-Konsep Dasar Penelitian Kualitatif. Makalah.Seminar Nasional Penenelitian Dosen FKIP/FIS.Surakarta:UNS

TIM Dosen FKIP IKIP Malang(1987).Pengantar Dasar Pendidikan. Malang:Usaha Nasional

Undang-Undang Dasar RI 1945 dan Amandemen Tahun 2002 BAB XIII Pasal 1 Ayat .(2002) Yogyakarta:Sendang Ilmu

Undang-Undang Sistem Pendidikan Nasional No 20 Tahun 2003 Bab II Pasal 3 (2003)Bandung:Fokus Media

Yusuf, M(1982) Pengantar Ilmu Pendidikan.Jakarta:Ghalia Indonesia

Yusuf, N.S.,dan Romdiyah(1989) Dasar-dasar Pendidikan.Tulungagung: F Tarbiyah IAIN Sunan Ampel 